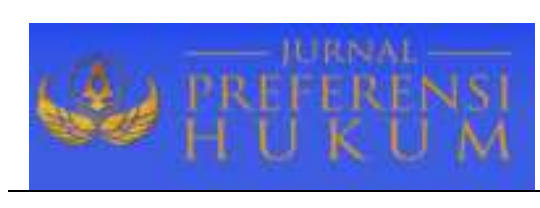

Jurnal Preferensi Hukum | ISSN: 2746-5039

Vol.2, No. 2 - Juli 2021, Hal. 276-281| Available online at

https://www.ejournal.warmadewa.ac.id/index.php/juprehum

DOI: https://doi.org/ 10.22225/jph.2.2.3322.276-281

\title{
IMPLEMENTASI PENGATURAN PEMBERIAN BANTUAN SOSIAL DALAM ERA PANDEMI COVID-19 DI DESA ADAT KUTA
}

\author{
Ni Komang Ayu Febriyanti, I Wayan Wesna Astara, I Wayan Arthanaya \\ Fakultas Hukum, Universitas Warmadewa, Denpasar-Bali, Indonesia \\ ayyufebril90@gmail.com, wesnaastara58@gmail.com, arthanaya.waya.@gmail.com
}

\begin{abstract}
Abstrak
Kesejahteraan umum merupakan upaya yang dilakukan pemerintah yang bertujuan untuk meningkatkan kesejahteraan masyarakat melalui pelayanan sosial serta memiliki ruang lingkup yang luas. Mewabahnya virus covid-19 di Indonesia mengakibatkan pemerintah pusat mengeluarkan kebijakan-kebijakan tentang upaya pencegahan penyebaran virus covid-19 yang harus dilaksanakan oleh pemerintah daerah. Tujuan penelitian ini untuk mengungkap pengaturan dana bantuan pemerintah daerah dalam rangka menanggulangi covid-19 di Desa Adat Kuta serta implementasi pemberian dana bantuan sosial yang disalurkan untuk masyarakat dalam rangka panderni covid-19. Metode yang digunakan adalah penelitian hukum empiris dengan pendekatan sosiologi. Sumber bahan hukum berupa primer, sekunder dan tersier yang didapat secara langsung melalui penelitian lapangan. Bahan-bahan hukum yang diperoleh kemudian dianalisis dengan menggunakan teknik deskriptif kualitatif. Hasil Penelitian ini menyimpulkan Desa Adat Kuta tidak memenuhi kriteria selektif dalam pemberian bantuan mengingat yang dilihat adalah aspek kesetaraan masyarakat adat dan dinas dan diperlukannya organisasi dan sistem pelaksanaan agar pemberian bantuan sosial dapat berjalan tepat sasaran.
\end{abstract}

Kata Kunci: Bantuan Sosial, Desa Adat Kuta, Pandemi Covid-19

\begin{abstract}
Public welfare is an effort made by the government which aims to improve the welfare of the community through social services and has a broad scope. The outbreak of the covid-19 virus in Indonesia resulted in the central government issuing policies on efforts to prevent the spread of the covid-19 virus which must be implemented by local governments. The purpose of this research is to reveal the arrangement of local government assistance funds in order to tackle covid-19 in the Kuta Traditional Village and the implementation of the provision of social assistance funds distributed to the community in the context of the Covid-19 pandemic. The method used is empirical legal research with a sociological approach. Sources of legal materials are primary, secondary and tertiary which are obtained directly through field research. The legal materials obtained then analyzed using qualitative descriptive techniques. The results of this research concluded that Kuta Traditional Village is not qualified in providing assistance considering that what was seen was the aspect of equality of indigenous peoples and agencies and the need for an organization and an implementation system so that the provision of social assistance can proceed well.
\end{abstract}

Keywords: Social Assistance, Kuta Traditional Village, Covid-19 Pandemic

\section{PENDAhUluan}

Akhir tahun 2019 dunia mengalami ketakutan akan tingkat kematian yang tinggi, hal tersebut diakibat oleh mewabahnya virus corona. Wuhan, China merupakan daerah atau negara pertama yang menjadi suspek penyebaran virus ini secara masif. Diduga virus corona ini sampai mewabah dikarenakan adanya kontak langsung antara manusia dengan hewan, yang dimana di Wuhan terkenal memiliki pasar yang memperdagangkan hewan yang cukup ekstrim untuk dikonsumsi.

Penyebaran virus corona ini dapat mewabah secara luas dan masif ke seluruh dunia dikarenakan mobilitas dari warga dunia yang selalu melakukan perjalanan kelintas negara dengan segala kepentingan mereka. Aki at yang ditimbulkan dari mewabahnya virus covid-19 ini adalah hampir semua kegiatan dilakukan dari rumah atau lebih dikenal dengan istilah work from home. Sektor pendidikan menerapkan metode pembelajaran daring yang dilakukan dari rumah siswa masingmasing, pemerintahan yang dimana setiap kantor pemerintahan rnengalami pengurangan pegawai pada jam kerja yang sebagai melakukan pekerjaanya dari rumah begitu juga dengan sektor industri lainnya dan dalam sektor pariwisata mengalami dampak yang paling besar, dikarenakan terjadinya 
pengurangan dan pembatasan kunjungan wisatawan baik itu wisatawan domestic ataupun intemasional.

Dengan dinyatakannya pandemi yang diakibatkan oleh virus covid-19 menjadi bencana nasional, maka pemerintah melakukan upaya menyiapkan daerah siaga covid-19, memberikan edukasi atau pembekalan kepada masyarakat ten tang apa itu covid-19, bagaimana penyebarannya terjadi dan apa yang dapat ditimbulkan jika terpapar virus covid-19 itu sendiri. Pemerintah juga berupaya dalam menyiapkan bantuan yang berupa bantuan sosial yang akan ditujukan kepada masyarakat, pemberian bantuan sosial tersebut bertujuan agar dapat membanru perekonomian masyarakat di masa pandemi ini. Sebelum terjadinya pandemi, pada masa Pemerintahan Presiden Susilo Bambang Yudhoyono pernah menerbitkan bantuan sosial bagi masyarakat dengan nama Bantuan Langsung Tunai atau lebih dikenal dengan BLT. Sedangkan pada awal masa Pernerintahan Presiden Joko Widodo, beliau juga mengeluarkan bantuan sosial nama Program Perlindungan Sosial. Kedua kebijakan yang pemah dikeluarkan oleh presiden dalam masa kepemimpinannya memiliki tujuan dan maksud yang sama, yaitu mengatasi kemiskinan di lingkungan rnasyarakat.

Pada masa pandemi ini pemerintah rnengupayakan dan mernberikan dana bantuan sosial kepada masyarakat melalui dana infrastruktur yang dialihkan ke desa dengan tujuan sebagai bantuan sosial bagi masyarakat di masa pandemi saat ini. Bantuan ini diberikan mengingat banyak masyarakat yang kehilangan mata pencahariannya atau di PHK dari pekerjaannya. Sehingga negara wajib memberikan sumbangsih bagi masyarakat dalam bentuk bantuan sosial.

Menurut pasal 1 ayat (1) UU No. 6 Tahun 2014, desa atau desa adat merupakan kesatuan masyarakat yang terikat oleh norma-norma atau hukum yang telah disepakati bersama sebagai acuan dalam bertingkah laku di lingkungan masyarakat, memiliki wilayah, memiliki kepentingan dari masyarakatnya yang berdasar pada prakarsa dari masyarakat dan hak tradisional dari masyarakat iru sendiri serta diakui dan dihormati oleh sistem Pemerintahan Negara Kesatuan Republik Indonesia.

Sebagai kesatuan masyarakat hukum dan memiliki wilayah, maka desa memiliki wewenang dalam mengatur, mengurus dan mengelola urusannya sendiri dengan tujuan untuk meningkatkan kesejahteraan masyarakatnya serta melakukan tindakan dengan upaya menanggulangi kemiskinan masyarakatnya melalui pemenuhan keburuhan dasar serta mengoptimalkan sumber daya a lam yang dimiliki oleh desa tersebut dengan seoptimal mungkin. Sebagai daerah yang mengganrungkan kehidupannya dari sektor pariwisata, Desa Adat Kuta mengalami dampak yang cukup besar, sehingga menimbulkan penurunan standar hidup dari masyarakatnya. Penurunan standar hidup dari masyarakat desa itu sendiri didasari pada ditutupnya akses pariwisata baik itu domestic maupun internasional oleh pemerintah pusat.

Berdasar pada banyaknya masyarakat yang di PHK oleh perusahaan tempatnya bekerja dan ditutupnya penerbangan baik domestic dan internasional yang mengakibatkan sektor pariwisata di Bali Khususnya di Desa Adat Kuta menjadi mati suri. Atas dasar tersebut Desa Adat Kuta melakukan musyawarah yang dalam pembahasannya membahas mengenai rencana pemberian banruan sosial bagi masyarakatnya, sehingga diharapkan masyarakatnya tetap bisa bertahan hidup di masa pandemi covid-19 ini.

Pemerintah melakukan berbagai upaya dalam membantu masyarakat pada masa pandemi Covid-19, salah satunya yaitu diberkannya bantuan sosial yang diharapkan program tersebut bisa berjalan dengan efektif (Khoiriyah et al., 2020). (Natasya \& Hardiningsih, 2021) berpendapat bahwa tujuan diberikannya bantuan sosial bertujuan untuk mengurangi risiko sosial yang ditimbulkan dari kondisi tertentu. Dengan kata lain bantuan sosial merupakan suatu penyaluran dana yang dimiliki pemerintah yang diberikan kepada masyarakat dengan beberapa syarat yang telah ditetapkan. Keseriusan pemerintah dalam menangani permasalahan yang terjadi selama pandemi yaitu dapat dilihat dengan banyaknya program yang telah dijalankan terkait meminimalisir masalah sosial dengan memberikan bantuan Program Keluarga Harapan (PKH), Bantuan Pangan Non Tunai (BPNT), Santunan Kematian, Bantuan Sosial Tunai (BST) dan Bantuan Sembako (Melati \& Zulkarnaini, 2021).

Maka berdasarkan uraian diatas, penelitian ini bertujuan untuk mengungkap pengaturan dana bantuan pemerintah daerah dalam rangka menanggulangi covid-19 di Desa Adat Kuta serta implementasi pemberian dana bantuan sosial yang disalurkan untuk masyarakat dalam rangka pandemi covid-19. 


\section{METODE PENELITIAN}

Tipe penelitian yang digunakan dalam penulisan ini adalah penelitian hukum empiris dan penguatan data dari penelitian ini dikuatkan oleh penelitian hukum normatif. Pendekatan secara empiris dilakukan dengan dengan pendekatan sosiologi, pendekatan sosiologis merupakan pendekatan yang dilakukan dengan mengkaji data-data dilapangan secara empiris dan menganalisis serta mempelajari adanya hubungan timbal batik antara hukum itu sendiri dengan gejala-gejala yang terjadi di masyarakat (Soekanto, 1989). Pendekatan masalah secara normatif dalam penelitian ini adalah pendekatan perundang-undangan dan pendekatan konseptual yang menekankan pada pandangan, doktrin-doktrin, serta peraturan-peraturan yang berkembang dalam ilmu hukum (Muhammad, 2004). Teknik pengumpulan bahan hukum yang digunakan adalah: bahan hukum primer yang didapat secara langsung melalui penelitian lapangan, yang berupa sejumlah informasi-inforrnasi penting menyangkut tentang judul atau tema penulisan ini dan informasi tersebut disampaikan oleh narasumber yang berkompeten akan tema tulisan ini. Bahan hukum sekunder didapat dari menganalisis buku-buku, jurnal-jurnal dan penelitian terdahulu yang merniliki keterkaitan dengan judul penulisan ini serta bahan hukum tersier yang dapat menunjang bahan hukum primer dan sekunder seperti kamus-karnus hukum dan tulisan yang dapat diakses melalui internet. Bahan-bahan hukum yang diperoleh kemudian dianalisis dengan menggunakan teknik deskriptif kualitatif, yaitu pengelolaan data yang dilakukan dengan menguraikan dan menggambarkan data yang diperoleh dari hasil penelitian empiris dan beberapa pengaturan yang menyangkut tentang pengguanaan dana bantuan sosial dalam era pandemi covid-19 di Desa Adat Kuta.

\section{HASIL DAN PEMBAHASAN}

\section{Pengaturan Dana Bantuan Pemerintah Daerah dalam Rangka Menanggulangi Covid-19 di Desa Adat Kuta}

Dana bantuan sosial merupakan dana yang bersumber dari keuangan negara. Dengan adanya pengelolaan terhadap keuangan negara, negara dapat mengalokasikan keuangannya dengan tujuan untuk menyelenggarakan pembangunan bangsan dan mensejahteraakan kehidupan masyarakatnya. Demi menyelenggarakan tujuan negara tersebut, maka negara mengalokasikan dana ke bidang infrastruktur, kesehatan, pendidikan dan dana bantuan sosial bagi masyarakat yang dianggap membutuhkan. Jika ditinjau secara mendalam, bantuan sosial dapat dikatakan jenis belanja pemerintah yang berupa klasifikasi ekonomi untuk melindungi masyarakat dari kemungkinan terjadinya risiko sosial, meningkatkan kemampuan ekonomi dan kesejahteraan masyarakat (Yusrizal, 2020). Hal ini termuat dalam Keputusan Menteri Sosial Republik Indonesia Nomor 54/HUK/2020 Tentang Pelaksanaan Bantuan Sosial Sembako dan Bantuan Sosial Tunai dalam Penanganan Dampak Corona Virus Disease 2019 (Covid-19) (Citra et al., 2021).

Pengelolaan keuangan negara dilakukan oleh negara yang mencakup beberapa proses di dalamnya, yang meliputi: penyusunan anggaran, penyelenggaraan anggaran dan pertanggungjawaban atas anggaran yang telah dikeluarkan. Data atas semua anggaran yang dikeluarkan oleh negara akan melalui proses audit untuk mengetahui apakah anggaran tersebut sudah tepat sasaran atau belum. Dalam konteks keuangan negara yang digunakan untuk kesejahteraan masyarakat dapat berupa dana bantuan sosial yang akan diserahkan langsung ke daerah dan pemerintah daerah memiliki tugas untuk mendata dan langsung memberikan bantuan sosial tersebut. Fungsi daerah otonom itu sendiri memiliki peranan penting dalam upaya penyaluran dana bantuan ini kedaerah, yang dapat memudahkan pemerintah daerah dalam penyaluran, administrasi dan pertanggungjawaban atas dana tersebut (Zuhro, 2010).

Dalam penerapan otonomi daerah pemerintah daerah pada hakikatnya merupakan perpanjangan tangan dari pemerintah pusat, yang dimana pemerintah daerah diberikan keleluasaan dalam mengatur daerahnya sesuai dengan ketentuan dan peraturan yang ditetapkan oleh pemerintah pusat. Atas dasar itulah pemerintah daerah berhak atas wewenang dalam mengatur daerahnya sendiri dan tetap diawasi langsung oleh pemerintah pusat (Bratakusumah, 2001). Mewabahnya pandemi covid-19 mengakibatkan pemerintah merancang dan menetapkan kebijakan-kebijakan yang bertujuan untuk menekan penyebaran dan memberikan penanganan terhadap virus covid-19. Salah satu kebijakan yang diterbirkan oleh pemerintah adalah Undang-Undang Nomor 6 Tahun 2014 dan Peraturan Pemerinrah Nomor 43 Tahun 2014 mengenai pelaksanaan dari Undang-Undang Nomor 6 
Tahun 2014 yang dimana keuangan desa didanai oleh APBDes dan APBN yang seluruh pendapatan desa tersebut disalurkan melalui kas desa yang penggunaanya ditetapkan melalui APBDes.

Menurut Peraturan Menteri Dalam Negeri Republik Indonesia Nomor 39 Tahun 2012 Tentang Pedoman Pemberian Hidan dan Dana Sosial yang Bersumber dari APBD adalah berupa pemberian uang atau barang dan bantuan layanan dari pemerintah kepada pemerintah daerah lainnya yang kemudian diteruskan ke masyarakat. Dalam pemberian hibah dan dana bantuan sosial, selain berpedoman pada Permendagri No. 32 Tahun 2011 dan Permendagri No. 39 Tahun 2012, maka pemberian hibah bersumber dari APBD danjuga diaturdalam PP No. 2 Tahun 2012 Tentang Hibah. Pemberian hibah dan bantuan sosial berpengaruh dalam menunjang kehidupan masyarakat di masa pandemi (Lapananda, 2015).

Selain peraturan-peraturan yang mengenai pemberian hibah dan bantuan sosial, pemerintah juga menerbitkan beberapa peraturan dalam masa pandemi covid-19 ini, yang meliputi: UU No. 2 Tahun 2020, Peraturan Menteri Keuangan No. 40 Tahun 2020, Peraturan Gubernur Bali No. 23 Tahun 2020, Peraturan Gubernur Bali No. 15 Tahun 2020, Peraturan Gubernur Bali No. 56 Tahun 2020 Diharapkan penerbitan dari peraturan-peraturan tersebut dapat membantu mengurangi penyebaran virus covid-19 serta dapat membantu masyarakat dalam menunjang kebutuhan nya selama masa pandemi ini. serta peraturan-peraturan tersebutlah yang menjadi acuan pemberian bantuan sosial bagi masyarakat oleh Desa Adat Kuta.

Penyaluran bantuan sosial tidak lepas dari pertumbuhan ekonomi masyarakat itu sendiri dan didasari oleh pelayanan Desa Adat. Bantuan sosial kepada masyarakat tidak hanya bersumber dari Desa Adat, melainkan juga bersumber dari kelurahan, Menurut narasumber yaitu Bapak Wasista selaku Bendesa Adat Kuta, menyatakan dana bantuan sosial bagi masyarakat dimasa pandemi juga bersumber dari kelurahan yang diantaranya berupa dana bagi pelaku UMKM di seputaran wilayah Desa Adat Kuta. Teknis dari penyaluran bantuan sosialnya dilakukan dalam beberapa tahap, yaitu: tahap pertama sebesar $60 \%$ dan paling cepat pencairannya bulan Maret dan paling Jambat pada bulan Juli, tahap kedua pencairannya sebesar $40 \%$ dan paling tepat bulan Agustus, Pencairan dana tersebut dapat dilakukan apabila masyarakat telah memenuhi kriteria sebagai penerima dana bantuan sosial tersebut.

\section{Implementasi Pemberian Dana Bantuan Sosial yang Disalurkan untuk Masyarakat dalam Rangka Pandemi Covid-19.}

Kriteria dari penerima dana bantuan sosial adalah masyarakat atau kelompok masyarakat yang memiliki bingkai resiko dan hubungan dengan desa baik itu berupa hak dan kewajiban sebagai warga desa. Dan bantuan sosial ini tidak akan diberikan kepada masyarakat atau kelompok masyarakat yang tidak merniliki bingkai resiko dan tidak merniliki kewajiban terhadap desa tersebut. Kriteria dari penerima bantuan sosial ini seperti yang telah ditetapkan dalam pasal 24 ayat (I) Permendagri No. 32 Tahun 2011, yang meliputi: selektif, memenuhi persyaratan penerimaan bantuan, bersifat sementara dan dapat dilanjutkan apabila terjadi keadaan tertentu serta sesuai dengan tujuan penggunaanya.

Sesuai dengan ketentuan dalam pasal 24 ayat ( I) Permendagri No. 32 Tahun 2011, Desa Adat Kuta tidak memenuhi syarat selektif dalam pemberian bantuan sosial. Hal tersebut dikarenakan Desa Adat Kuta menganggap baik itu masyarakat adat atau masyarakat dinas dianggap memiliki kewajiban yang sama serta berhak atas hak yang sama. Itu terjadi karena Desa Adat Kuta lebih mengedepankan ra a keadilan bagi masyarakatnya baik iru masyarakat adat ataupun masyarakat dinas. Yang dapat dikatakan berhak sebagai penerima dana bantuan sosial adalah mereka yang terdaftar sebagai penduduk asli ataupun mereka yang sebagai penduduk pendatang yang dimana telah terdata dalam data dari masing-masing banjar yang ada di Desa Adat Kuta.

Berdasar pada hasil wawancara dengan Bapak Wasista selaku Bendesa Adat Kuta, beliau menyatakan bahwa pada tanggal 8 Januari 2021 Desa Adat Kuta telah memberikan 380 paket sembako kepada kelian Banjar Segara Kuta sebagai salah satu banjar di Desa Adat kuta. Diharapkan pembagian paket sembako tersebut terbagi secara merata kepada masyarakat, tetapi apabila ada masyarakat yang merasa mampu dan tidak memerlukan bantuan tersebut, maka bantuan tersebut akan disimpan terlebih dahulu dan diberikan kepada masyarakat yang dianggap kurang mampu.

Bantuan sosial merupakan salah satu upaya pemerintah dalam melaksanakan tugas-tugasnya dalam melayani public sesuai dengan kewenangan yang ada. Implementasi dari pemberian bantuan sosial tidak hanya dapat berupa pengeluaran dalam bentuk uang dan barang, melainkan dapat berupa 
penyediaan atau perbaikan infrastruktur yang dapat mempermudah mobilitas masyarakat sehingga bisa membantu perekonomian masyarakat.

lmplementasi dari pemberian bantuan sosial di desa adat kuta sudah dimulai pada pertengahan tahun 2019. Pemberian bantuan sosial tersebut pada dasarnya bertujuan untuk meringankan beban bagi masyarakat yang dirasa tidak mampu dan terlantar sehingga dapat memenuhi kebutuhan dasar hidupnya dan dapat mengembankan potensi nya sebagai manusia sesua dengan kemanusiaan yang bermartabat sebagai arnanat konstitusional. Implementasi dari pemberian dana sosial membutuhkan organisasi dan sumber daya manusia yang bagus dalam pelaksanaanya. Sumber pendanaan dari pemberian dana bantuan sosial bersumber dari APBD dan juga bersumber dari pendapatan asl i desa yang merupakan kas desa, serta dibantu juga oleh anggota dewan yang memiliki daerah pemilihan di desa tersebut.

Demi memperlancar dalam mengimplementasikan dana bantuan sosial, Desa Adat membentuk satgas gotong royong. Satgas gotong royong tersebut bertugas untuk memberikan sosialisasi perihal pencegahan dari penyebaran virus covid-19. Satgas gotong royong juga berperan aktif dalam memberdayakan masyarakat dan bertugas sebagai pelaksana tugas dalam penyaluran dana bantuan sosial ke masyarakat. Selain menerima hak atas bantuan sosial, masyarakat juga serta merta memiliki kewajiban dalam melaksanakan protocol kesehatan dengan tujuan dapat mengurangi penyebaran virus covid-19. Apabila terjadi pelanggaran terhadap protocol kesehatan yang sudah ditentukan oleh desa, maka pecalang dan satgas gotong royong berhak memberikan sanksi bagi pelanggarnya sesuai dengan perintah dari Bendesa Adat.

Dengan upaya gotong royong yang dilakukan oleh seluruh elemen masyarakat khususnya di wilayah desa adat, diharapkan dapat mencegah penularan atau penyebaran dari virus covid-19 ini. Dan dengan diberikannya bantuan sosial diharapkan masyarakat dapat bertahan di masa pandemi yang terjadi saat ini serta berharap pariwisata di Pulau Dewata akan pulih kembali.

\section{SIMPULAN DAN SARAN}

\section{Simpulan}

Pengaturan dalam pemberian bantuan sosial bagi masyarakat di Desa Adat Kuta dalam konteks upaya penanganan covid-19 didasari oleh Peraturan Daerah No. 4 Tahun 2019. Dan sesuai dengan Permendagri No. 32 Tahun 2011 pada pasal 24 ayat (1) Desa Adat Kuta tidak menerapkan kriteria penerima bantuan sosial sesuai dengan bunyi pasal tersebut, hal ini terjadi karena Desa Adat Kuta ingin secara adil memberikan bantuan sosial kepada masyarakatnya, baik itu masyarakat adat atau masyarakat dinas, yang dimana keduanya memiliki kewajiban dan hak yang sama di Desa Adat Kuta. Adapun Implementasi dari kebijakan pemberian bantuan sosial kepada masyarakat di Desa Adat Kuta berupa uang maupun barang, telah dilakukan sesuai dengan instruksi dari pemerintah daerah provinsi Bali dari awal perencanaan, pelaksanaan dan pertanggungjawabannya. Diperlukannya organisasi yang melibatkan segala elemen masyarakat serta memiliki kualitas sumber daya organisasi yang memadai demi melaksanakan pemberian dana bantuan sosial di Desa Adat Kuta.

\section{Saran}

Untuk pemerintah, diperlukannya komunikasi yang jelas dan terarah kepada masyarakat, agar masyarakat paham mengenai bantuan sosial yang diberikan serta masyarakat juga harus melakukan pelaporan atas penerimaan bantuan sosial tersebut secara mandiri. Pemerintah juga perlu melakukan kerja sama dengan pihak swasta agar pemenuhan bantuan sosial bagi masyarakat dapat mencakup masyarakat yang lebih luas. Untuk Desa Adat Kuta, diharapkan agar pelaksanaan sosialisasi dilakukan melalui forum resmi dengan pembahasan menyangkut tentang protokol kesehatan dan pemberitahuan mengenai pendataan bagi calon bakal penerima bantuan sosial disampaikan dengan jelas dan seksama kepada masyarakat. Untuk masyarakat, diharapkan agar penerimaan hak berupa bantuan sosial yang diberikan oleh Desa Adat Kuta berjalan lurus dengan kewajiban masyarakat dalam mematuhi protocol kesehatan yang telah ditetapkan oleh pemerintah. 


\section{DAFTAR PUSTAKA}

Bratakusumah, D. S. (2001). Otonomi Penyelenggaraan Pemerintan Daerah. PT Gramedia Pustaka Utama, Jakarta.

Citra, S. F., Muzalifah, T., \& Ibrahim, L. (2021). Analisis Kesesuaian Penerima dan Penggunaan Dana Bantuan Sosial Pandemi Covid-19 pada Masyarakat Gampong Sapik dan Gampong Air Berudang, Aceh Selatan. Jurnal Riset Dan Pengabdian Masyarakat, 1(1), 12-23.

Khoiriyah, F., Oktavia, L., Zakiyah, N., \& Huda, M. A. I. (2020). Efektivitas Pelaksanaan Bantuan Sosial dari Pemerintah Terhadap Masyarakat Terdampak Covid-19 di Desa Gendongarum Kecamatan Kanor Kabupaten Bojonegoro. Jurnal Spirit Publik, 15(2), 97-110.

Lapananda, Y. (2015). Hibah dan bantuan sosial yang bersumber dari APBD. Sinar Grafika, Jakarta.

Melati, \& Zulkarnaini. (2021). Efektivitas Program Bantuan Sosial Tunai pada Masa Pandemi Covid19 di Kelurahan Pasir Pengaraian. Journal Publicuho, 4(1), 19-26.

Muhammad, A. (2004). Hukum dan Penelitian Hukum. PT Citra Adirya Bakti, Bandung.

Natasya, V., \& Hardiningsih, P. (2021). Kebijakan Pemerintah Sebagai Solusi Meningkatkan Pengembangan UMKM di Masa Pandemi. Ekonomis: Journal of Economics and Business, 5(1), 141-148.

Soekanto, S. (1989). Mengenai Sosiologi Hukum. Citra Adirya Bakti, Bandung.

Yusrizal. (2020). Tanggung Jawab Negara Terhadap Pengawasan Bantuan Sosial Selama Pandemi Covid-19. Suloh: Jurnal Program Studi Magister Hukum, 8(2), 21-36.

Zuhro, R. S. (2010). Kisrun Peraturan Daerah: Mengurai Masalah dan Solusinya. Ombak, Yogyakarta. 